\section{SOI: 1.1/TAS DOI: 10.15863/TAS \\ International Scientific Journal Theoretical \& Applied Science}

p-ISSN: $2308-4944$ (print)

e-ISSN: 2409-0085 (online)

Year: 2015

Issue: 04

Volume: 24

Published: 30.04 .2015

\section{http://T-Science.org}

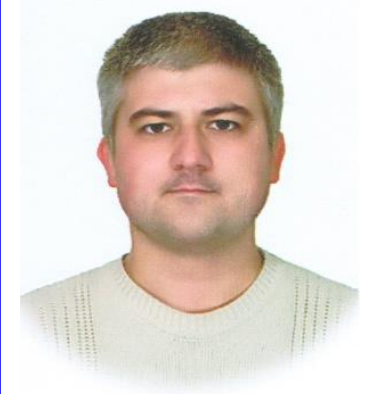

Alexey A. Ryzhenko

Research associate, Candidate of technical sciences, State Fire Academy of EMERCOM of Russia, Russia litloc@rambler.ru

SECTION 4. Computer science, computer engineering and automation.

\title{
MODELING OF THE COGNITIVE CENTER OF SUPPORT OF MANAGEMENT OF SAFETY OF LARGE-SCALE OBJECTS
}

\author{
Abstract: At present, majority of complex systems of support of management of difficult systems reconsider the \\ main architecture in connection with a set of practical problems. This paper discusses an option of use of several \\ technologies in uniform system with the central management. \\ Key words: cognitive control center, complex safety, system of systems. \\ Language: English \\ Citation: Ryzhenko AA (2015) MODELING OF THE COGNITIVE CENTER OF SUPPORT OF \\ MANAGEMENT OF SAFETY OF LARGE-SCALE OBJECTS. ISJ Theoretical \& Applied Science 04 (24): 80- \\ 85. \\ Soi: http://s-o-i.org/1.1/TAS*04(24)14 Doi: crossef http://dx.doi.org/10.15863/TAS.2015.04.24.14
}

\section{Introduction}

The large cities are characterize by frequent congestions of mass of people on limited squares, in the closed spaces. The usual daily situation assumes the free mode of pastime - an entrance, internal actions, and an exit. In case of an emergency flows of people often turn into the uncontrollable unorganized crowd capable to do themselves bigger harm, than a danger source. This situation assumes preliminary preparation for possible scenarios of development of an emergency from departments of EMERCOM of Russia, demands joint purposeful actions, participation of a complex of the various automated systems of monitoring, control and coordination as actions of the personnel and the arriving services of rescue, and human streams. The situation is significantly aggravated on the spatial distributed large-scale objects, such as parks or recreation areas, cultural or shopping centers, etc.

\section{Discussed problems}

Historically it developed so that on objects of a mass congestion of people some types of the no interacting or partially interacting automated systems are, as a rule, established: systems of monitoring (cameras, sensors, etc.), monitoring systems (racks, gate, etc.), and systems of coordination (indexes of ways of evacuation, alarm system, etc.) and other systems. During the stable work of one of them, for example, of life support systems, others, for example, systems of fire safety can cause infinite collisions which standard algorithms of "search of decisions" cannot almost be resolved. The existing models of obtaining alternative decisions "overloaded" already at the first stages.

The exit from this situation offers to use complex system of systems in the form of the cognitive control center capable to interact with special services, services of utilities, and the third parties (participants of process) in the constant and operational modes. The developed center assumes not only multipurpose algorithms of possible situations and ways of their decisions, but also the limited list of hardware allowing to act as necessary and sufficient tools during decision-making.

1. Features of formation of elements of the cognitive centre

\subsection{Hierarchy in a control system}

The exit option from this situation is present in article, the concept and the mechanism of the information environment over the automated systems and participating the operating structures in the form of the uniform cognitive center is offer. The offered option means the joint work of a real and virtual component within one center, and the distributed network of the interacting structures.

As the main model of a control system for the cognitive center in the project, the three-level hierarchy is accept to use (to similarly unified control system in the organizations, Fig. 1).

At the lower level monitoring systems in real time, settle down: systems of video surveillance, motion sensors, temperatures, pressure, laser and 
radio systems, etc. The main destination monitoring of reality, instant capture of possible changes. The received information is transfer to systems analytics that allow storing multimedia information, to form the superficial forecast of possible scenarios of development of the current situation. Use of various systems of support of decision-making for the cognitive center at this level allows building scenarios, to prevent insignificant emergencies at an early stage of development $[1,3$, 9-10].

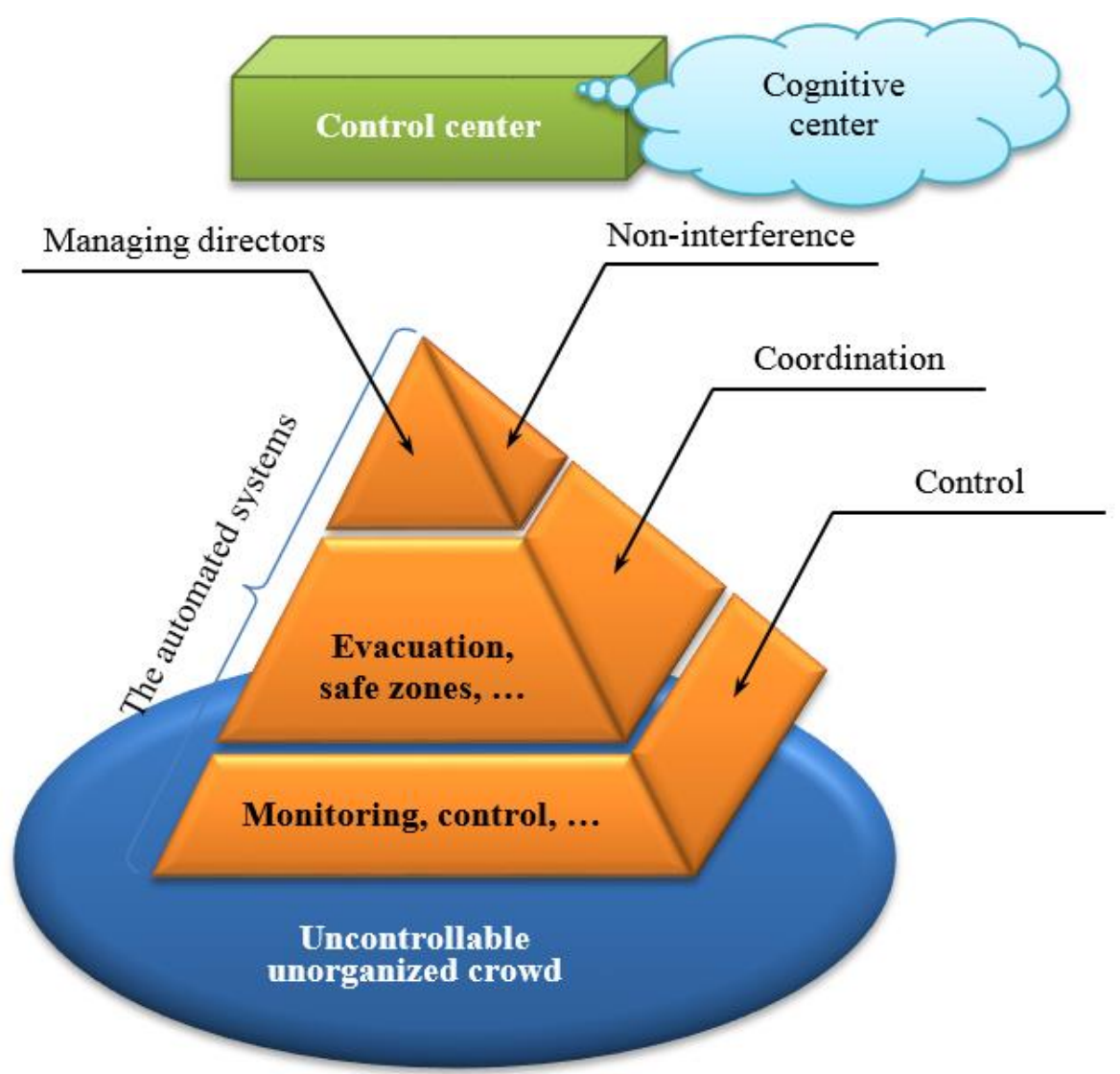

Figure 1 - A pyramidal control system of the automated systems of the cognitive center.

At the average level, the operating systems of coordination of objects of the social environment settle down: evacuation, alignment of forces and means, positioning of safe zones, zones of special attention and zones of possible or actual emergencies, etc. For this level introduction, the project in functionality of the cognitive center of multilayered system of facet positioning (Fig. 2) is suppose. The technology allows reducing requirements to the used resources for moment fixing of the condition of a controlled zone distributed in time and space.

\subsection{Flexible system of support of management}

The algorithm and the principle of decisionmaking is under construction as follows: the virtual computer of the center is form based on threedimensional geoinformation technology with use of multilayered composition. Each top level adds a new task and new object on the modelled surface. Four categories of layers are allocate: a schematic map in the form of the flat image and a substrate at the same time, the modelled three-dimensional surface, area of attention and an emergency site (the fixed contour and specification of accident). In the absence of category of object, the unnecessary layer is not display and not model.

For formation of each separate layer, the technology of creation of a surface with use of a uniform grid and masking is used. The substrate is transfer to the mode of gradation gray for definition of a roughness of a surface, identification of heights and lowlands; the card of a surface (the second category of layers) is under construction. Then models of artificial objects and objects of the nature without specification and drawing skins are putting. These levels (layers) use modern filters and game "kernels" for formation of models of the big areas with objects at the minimum expenses of resources. The base of characteristics, parameters and the current indicators of monitoring systems of the lower level only in text form is consolidate to each object. 
The analyzed area breaks into attention areas (the third category of layers). For each area, components of the lower level and border of normal functioning are define. At change of a condition of indicators of the lower level with an exit out of limits of borders, area passes into the mode of special attention (it is visually designate in other color). Thus, the layer of the top category - specification of accident to a full translation is add to the mode of normal functioning [10].

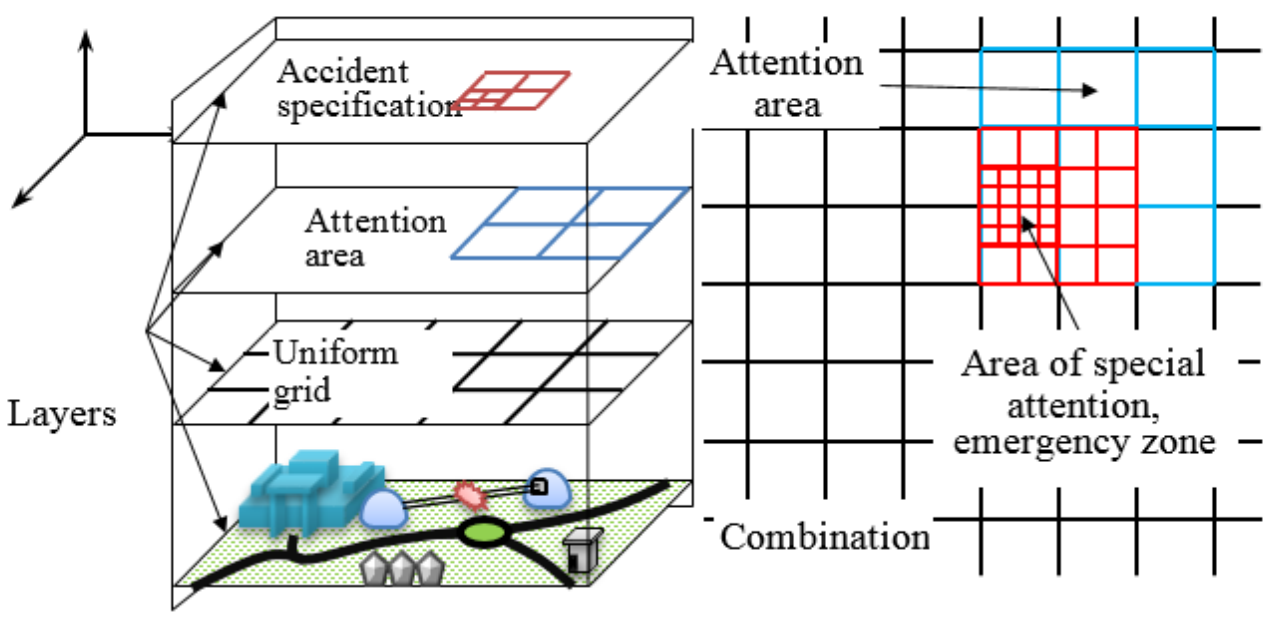

Figure 2 - The scheme of the analysis of a task for the cognitive center in case of definition potential an emergency at a stage of definition of potentially dangerous source or a factor of danger.

The top category of layers (accident specification) has the built-in feature - the uniform grid when modeling has floating border, specification is available. If necessary, the size of the constructed cell can be change, reduced to the minimum one pixel fortune. This effect allows to save hardware resources and to display difficult objects at the same time. In addition, at creation of objects, the principle of dual modeling that promotes reduction of requirements to resources is used $[2,5-6,11]$.

At the top level of the cognitive center, the system of support of management settles down. The offered information system has three characteristics distinguishing it from modern analogs:

i) built-in architecture uses the SoS or "system of systems" mechanisms allowing to operate system without interfering with the main processes;

ii) use of the principle of feedback at coordination of streams of human masses, alignment of forces and means and other mass actions with use of resources of three-dimensional geographic information systems;

iii) built-in mechanism of fast formalization of processes at adoption of operational decisions using technology of a set from the whole.

\section{Interpretation of the used mechanisms}

\subsection{First mechanism}

The principle of SOS for the modern difficult systems, which are not allowing operating themselves in an explicit form (Fig. 1), is used. The principle of non-interference assumes stable work of the system existing and operating in real time irrespective of actions of the operating link, and only in case of need to connect additional tools [2]. This principle is in detail considered as in the Russian and foreign works and is widely use for many systems, such as: worldwide network Internet, alternative power engineering, large-scale military tactics, design mechanical engineering, etc. We will give an example of the non-standard solved task: in the closed pavilion of the cultural center, sensors recorded a sudden power failure in networks, temperature increase and density of air. Reaction of the cognitive center:

i) control system of a contour gives signal on operation and shutdown of the line of food, but the system doesn't pass into emergency operation;

ii) warning system warns 3 persons: "For technical reasons the attraction is temporarily closed on a break" where phrases "A request to leave the room" isn't present. Then "In 10 minutes the attraction opens ..., the bought tickets are valid in all territory of the center" designation of a safe zone and preferential terms for fast evacuation;

iii) communication system causes rescue services to the place of accident through the dispatcher and the control panel, informs a key element of the center about the current situation;

iv) geographic information system designates points of an arrangement of forces and means, ways of evacuation and safe zones taking into account heights of a relief and artificial objects; 
v) built-in system of storage of operational information provides the information on estimated number of 3 persons on the basis of indications of systems of the lower level;

vi) system of video fixing is reoriented on a dangerous site for ensuring operational remote management;

vii) also additional participating systems are possible.

\subsection{Second mechanism}

The closed three-dimensional geoinformation model is applied. Many existing information systems do not assume use of full functionality of threedimensional model of a surface. Moreover, the existing mathematical techniques determining scales of possible defeat do not consider a land relief, existence of artificial obstacles that promotes incorrect definition of zones of possible defeats. In system of the cognitive center, the three-dimensional geoinformation model with feedback is used. The loop allows to analyze the third coordinate (height) and to consider it at coordination of the social environment in an operational situation [1, 4]. We will give an example of use of the mechanism: the territory of the cultural center has eight wide multiband exits on two from each party. At emergence potential, the emergency made the decision on evacuation out of limits of the territory of the population, which is present now. Systems of the lower level recorded that passenger vehicles that represents artificial obstacles of the increased complexity encumber the next main exits. To organize coordination of evacuation from the territory, using other main exits, and additional if necessary. To provide delivery of rescuers to a place of an emergency (green channel). Reaction of the cognitive centre:

i) the system uses additional layers on the geoinformation card, closes the next exits and redistributes evacuation streams;

ii) there is a notification of coordinators (security services and first aid) about possible ways of evacuation, and also all necessary parameters;

iii) in the operational mode there is a reorientation of system of video fixing for ensuring remote management;

iv) also additional participating systems are possible.

\subsection{Third mechanism}

The set from whole is used that allows to describe prime numbers objects and processes of the lower and average level, and also the current indicators of the controlling systems, to lead them to a general view for adoption of the operational decision [2, 7-8]. The example of the decision is present in Fig. 3.

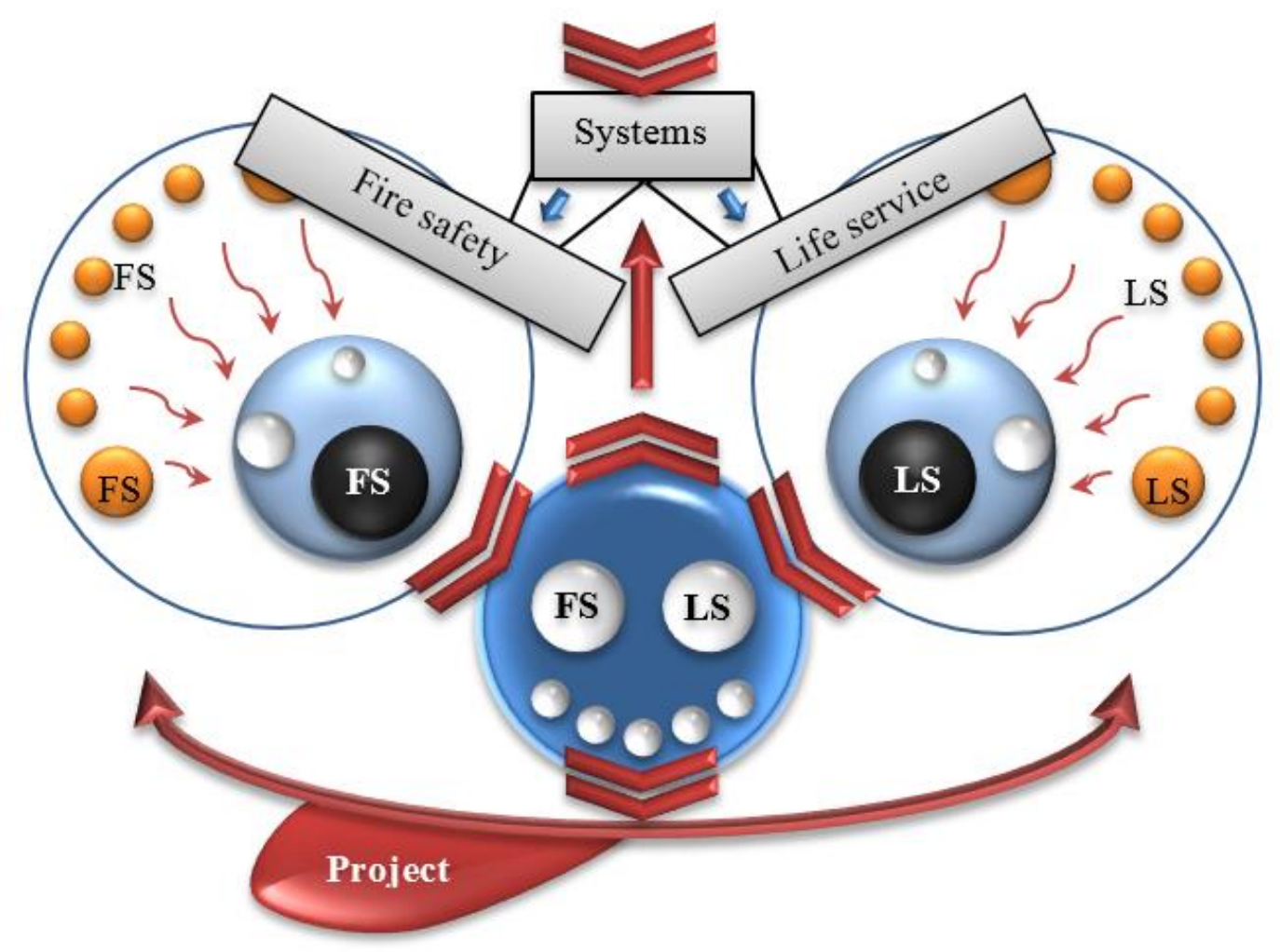

Figure 3 - The block diagram of formation of the project at emergence of a non-staff situation. 
On the operated sites, the cognitive center uses two independent systems: fire safety and life service, according to a set of the entering systems we designate $F S$ and $L S$. At direct use of both systems there is a set of collisions, one system "stirs" another. The limited sets of systems allocated for the solution of the current tasks are designated by $F S_{x}$ and $L S_{y}$ and necessary for the project (for example, urgent evacuation from the building and collecting in a certain territory) $F S_{p}$ and $L S_{p}$. Therefore, function of transformation of processes (1):

$$
\sum_{i=1}^{N}[F S]_{i}+\sum_{j=1}^{M}[L S]_{j} \underset{F S_{x}+L S_{y}}{\longrightarrow}[F S+L S]_{p} .
$$

We will give an example of use of the presented function for formalization of tasks at decisionmaking: in pavilion of the cultural center, there are six components of system of fire safety and eight life support systems. In the regular mode all components operating. At local transfer of system in the emergency mode three operating components of fire safety, four life support (from them two constantly acting and two in a reserve), and three additional components of system of monitoring used out of object are necessary. Formally, the task can be present in the form (2):

$$
3+[3]+[2+2]+4 \underset{10}{\rightarrow} 7
$$

where "10" - an indicator whole or quantity of the operating components, "7" quantity of components of the object [2].

\section{Conclusions}

The described tools of hierarchical information system are supposed to be use for the centers of ensuring complex safety of the spatial distributed objects with mass stay of people. Essential advantages are define by new mechanisms of processing of big data files in a whole that will allow simplifying and accelerating decision-making process.

\section{Acknowledgements}

Russian Federal Property Fund (projects 14-0700205-a, 14-07-00257-a) supported the research work.

\section{References:}

1. Topolsky NG, Khabibulin RS, Ryzhenko AA, Bedilo MV (2014) "Adaptive system support of Center for Crisis Management": Monograph ["Adaptivnaya sistema podderzhki deyatelnosti centrov upravleniya v krizisnyx situaciyax", Monografiya], State Fire Academy of EMERCOM of Russia, Moscow, 151 p.

2. Topolsky NG, Maximov IA, Ryzhenko AA (2014) "Dual modeling graphics processing system to support management of rescue and restoration measures": Monograph ["Dualnoe modelirovanie obrabotki graficheskix dannyx sistemy podderzhki upravleniya avarijnovosstanovitelnymi meropriyatiyami", Monografiya], State Fire Academy of EMERCOM of Russia, Moscow, 149 p.

3. Ryzhenko AA (2005) "Development and realization adaptive system information support of management industrial and ecological safety of large enterprise": Dissertation Autoabstract on the degree of Candidate of Technical Sciences ["Razrabotka i realizaciya adaptivnoj sistemy informacionnoj podderzhki upravleniya promyshlenno-ekologicheskoj bezopasnostyu krupnogo predpriyatiya", Avtoreferat dissertacii na soiskanie uchenoj stepeni kandidata texnicheskix nauk], Institute of the system analysis of the Russian Academy of Sciences. Moscow, $21 \mathrm{p}$.

4. Ryzhenko AA, Khabibulin RS (2012) "Information imaging explosion and fire at industrial sites enterprises", Works of KSC Russian Academy of Sciences: Collected papers ["Informacionnaya texnologiya vizualizacii vzryvov i pozharov na proizvodstvennyx obektax", Trudy KNC RAN. 4/2012(11)], Information technologies. Release of III, Apatity, pp. 186-190.

5. Topolsky NG, Maximov IA, Ryzhenko AA, Kadyrov HK (2013) "Use method of threedimensional modeling destructions", Materials of the 22nd international scientific and technical conference "Security Systems - 2013": Collected papers ["Ispolzovanie metoda tryoxmernogo modelirovaniya razrushenij", Materialy 22-j mezhdunarodnoj nauchnotexnicheskoj konferencii «Sistemy bezopasnosti - 2013»], State Fire Academy of EMERCOM of Russia, Moscow, pp. 389-391.

6. Maximov IA, Topolsky NG, Ryzhenko AA (2014) "Way of modelling of the destroyed buildings in the analysis of materials of insurance fund of documentation of emergency situations", Technologies of a technosphere safety: Collected papers ["Sposob 
modelirovaniya razrushennyx zdanij pri analize materialov straxovogo fonda dokumentacii po chrezvychajnym situaciyam", Texnologii texnosfernoj bezopasnosti], Internet magazine (http://ipb.mos.ru/ttb), Release No. 2 (54).

7. Ryzhenko AA (2014) Algebraic approach of the operated processes modeling of difficult systems // American Journal of Control Systems and Information Technology, 2014. - T. 4, No. 2. - pp. 17-21.

8. Ryzhenko AA (2015) Method of modeling of the operated processes of difficult systems. Modern informatization problems: Proceedings of the XX-th International Open Science Conference (Yelm, WA, USA, January 2015) / Editor in Chief Dr. Sci., Prof. O.Ja. Kravets. Yelm, WA, USA: Science Book Publishing House, 2015. - pp. 191-196.

9. Ryzhenko AA (2014) "About new approach to modeling processes management of complex security systems", Materials of the 23nd international scientific and technical conference "Security Systems - 2014": Collected papers ["O novom podxode $\mathrm{k}$ modelirovaniyu processov upravleniya kompleksnymi sistemami bezopasnosti", Materialy 23-j mezhdunarodnoj nauchno-texnicheskoj konferencii «Sistemy bezopasnosti - 2014»], State Fire Academy of EMERCOM of Russia, Moscow, pp. 29-33.

10. Ryzhenko AA (2014) "Hierarchy management of security systems", Materials of the 23nd international scientific and technical conference "Security Systems - 2014": Collected papers ["Ierarxiya upravleniya sistemami bezopasnosti", Materialy 23-j mezhdunarodnoj nauchno-texnicheskoj konferencii «Sistemy bezopasnosti - 2014»], State Fire Academy of EMERCOM of Russia, Moscow, pp. 36-38.

11. Ryzhenko AA (2014) "The mechanism of modelling of chips and splinters of the destroyed objects of the difficult form", Works of KSC Russian Academy of Sciences: Collected papers ["Mexanizm modelirovaniya skolov i oskolkov razrushennyx obektov slozhnoj formy, Trudy Kolskogo nauchnogo centra. Informacionnye texnologii, Vyp. 5, 5/2014(24)], Information technologies. Release of III. Apatity, pp. 204-214. 